\title{
An Analytic Review on the Factors that Affect Technology Acceptance Model (TAM) in Iranian Universities
}

\author{
Mehran Dastorani, ${ }^{1}$ and Zohreh Khoshneshin ${ }^{2,}$ \\ ${ }^{1}$ Educational Technology Department, Faculty of Psychology and Education, Kharazmi University, Tehran, IR Iran \\ ${ }^{2}$ Assistant Professor, Department of Educational Technology, Faculty of Psychology and Education, Kharazmi University, Tehran, IR Iran \\ "Corresponding author: Zohreh Khoshneshin, Assistant Professor, Department of Educational Technology, Faculty of Psychology and Education, Kharazmi University, Tehran, \\ IR Iran. Tel: +98-218697234, E-mail: khoshneshin@khu.ac.ir
}

Received 2017 April 09; Accepted 2017 May 22.

\begin{abstract}
Background: The present study aimed at investigating the factors that may influence users' perspectives in technology acceptance in universities of Iran. An extended model of the technology acceptance model (TAM), with emphasis on the impact of internal factors on technology acceptance concerning university teachers' points of views in Iran was considered in this research.

Methods: We conducted a surveyed research on teaches' points of view on acceptance technology based on TAM at Mashhad university. In this study, the sample was selected using random stratified sampling method from among 5 faculties of the governmental university in Mashhad in 2015. Approximately 150 teachers answered the researcher-made Likert-type questionnaire. The questionnaire validity and reliability were estimated in advance. Data were analyzed by the SPSS software (version 20); Chi-Square and Pearson correlation coefficients formula were also used.

Results: The results revealed a relationship between technology acceptance and the survived factors including behavioral intention, perceived ease of use, content quality, system accessibility, subjective norm, and e- learning self-efficacy, which were orderly estimated by $0.323,0.656,0.494,0.258$, and 0.624 , respectively $(\mathrm{P}<0.01)$.

Conclusions: An improvement in the approach to technology acceptance in universities necessitates the modification and reinforcement of the structures and substructures of the equipment concerned with technology.
\end{abstract}

Keywords: Technology, Education, Information, Acceptance Process

\section{Background}

As a recent trend in higher education has been to set up e-learning systems with online access and learning content through universities, it was aimed at developing a model of using technology as technology acceptance model (TAM). The model was firstly described by Davis (1989) in his psychometric research. TAM is able to investigate the factors of user's behavior towards using information technology or adopting new technologies. TAM is considered as the most frequent referred model for analyzing users' behavior in accepting technology.

In TAM model, as one of the most popular theories, 2 factors of perceived usefulness and perceived ease of use are relevant in computer use behaviors. Davis defines perceived usefulness as the prospective user's subjective probability that using a specific application system will enhance his or her job or life performance. Perceive ease of use (EOU) can be defined as the degree to which the prospective user expects the target system to be free of effort. According to TAM, ease of use and perceived usefulness are the most important determinants of actual system use (1).
Technology acceptance model has been widely used to explain information system usage. As Davis explained the model in his doctoral thesis, it has a descriptive approach to the main factors affecting the technology usage (2). The main factors, which are supposed to make the basic type approach of TAM model, are explained in Figure 1.

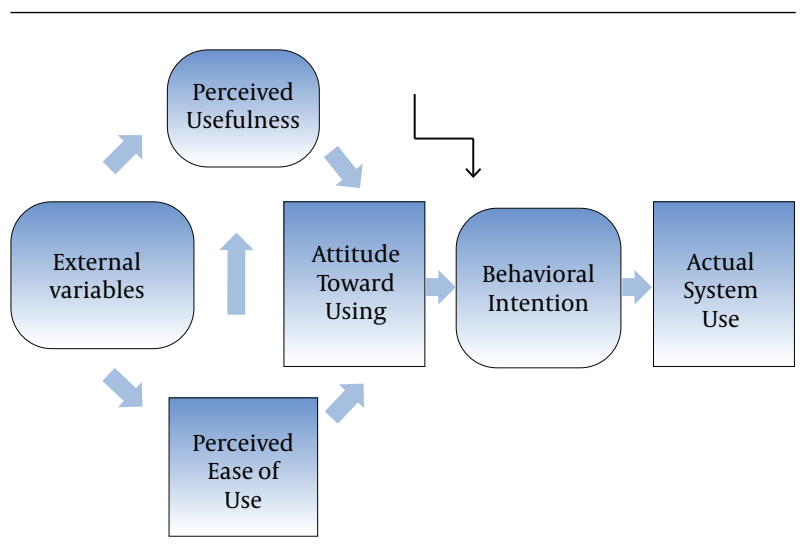

Figure 1. Technology Acceptance Model (TAM) Davis et al. (1989)(2) 
The perceived usefulness factor and perceived ease of use factors are major factors in computer use behaviors based on technology acceptance model (3). By referring to Davis and others confirmation on the impacts of factors such as ease and usefulness of technology on affecting the applications of technology, it seems a logical and rational approach for technology usage (Mathieson) (4).

As it is explained by TAM, ease of use and perceived usefulness are the most important determinants of actual system use. These 2 factors are influenced by external variables; however, the impacts of external factors are neglected by Davis as he wanted to have a general model to be designed for it. Considering the type of questions in Davis questionnaire, it is illustrated that perceived ease of use is a good indicator to explain the applicable abilities to use technology in contrast with the needed skills (5).

Several researches emphasized the impacts of the factors explained in TAM. The results of a research prepared by Van Raaij and Schepers (6) on technology acceptance model for virtual learning environment (VLE) in China indicated that perceived usefulness has a direct effect on VLE use. Perceived ease of use and subjective norm have indirect effects via perceived usefulness. Both personal innovativeness and computer anxiety have direct effects on perceived ease of use.

The results of the study prepared by Sun et al. (7) revealed that learner computer anxiety, instructor attitude toward e-learning, e-learning course flexibility, e-learning course quality, perceived usefulness, perceived ease of use, and diversity in assessments are critical factors affecting learners' perceived satisfaction. The results show the institutions how to improve learner satisfaction and further strengthen their e-learning implementation.

Nicholas (8) study on the computers, motivation, and perceived satisfaction from the e-learning system revealed that perceived satisfaction, intrinsic motivation, and shortcoming level of skills to use the system affect technology acceptance.

Yuen and Ma (9) found that computer self-efficacy and perceived ease of use were able to explain 0.68 of the variance observed in users' intention to use the e-learning system.

Kim (10) study on information technology acceptance in the internal audit profession showed that technology complexity (TC) can be explained as an individual's perception of understanding difficulty and using a new technology.

In a study, Kunda and Brooks (11) assessed the important factors that support information technology development in developing countries and revealed 4 factors of shortcoming facilities, less skilled manpower, economic boundaries, and structural limitation of technology as fac- tors affecting technology acceptance.

Paola Torres Maldonado et al. (12) determined the role of e-learning motivation and social factors in the use and adoption of e-learning systems and conversely the effect of technology on students' e-learning motivation. They found that motivation and social factors have positive effects on behavioral intention, but system accessibility and structural facilities do not. The impacts of age and geographic religion on acceptance of technology using social networks as a mediator variable were studied and their effects on e-learning system acceptance were confirmed (13).

Rocha et al. (14) on their study on improving energy efficiency via smart building energy management illustrated that companies must provide better data quality such as improving the compatibility of database.

Comparative analysis of existed perspectives on technology acceptance in Iranian Universities indicated that proper intention to accept technology is not enough when people are faced with boundaries like inadequate facilities. However, the mentioned interpretation would be modified if the system pay more attention to prepare qualified facilities and to technology applicants' intrinsic motivation. Universities are supposed to have programs to reinforce their personnel experiments, self-efficacy, and motivation to use technology and meanwhile make them feel less stress when in technological environment. Thus, the present study aimed at scrutinizing the factors that affect technology acceptance as figured out in TAM. Here we pose 6 questions:

1) Perceived usefulness has effects on teachers' behavioral intention to accept technology as e-learning system.

2) Perceived ease of use has effects on teachers' behavioral intention to accept technology as e-learning system.

3) Content quality has effects on teachers' behavioral intention to accept technology as e-learning system.

4) System accessibility has effects on teachers' behavioral intention to accept technology as e-learning system.

5) Subjective norm has effects on teachers' behavioral intention to accept technology as e-learning system.

6) E-learning self-efficacy has effects on teachers' behavioral intention to accept technology as e-learning system.

\section{Methods}

Surveying method was selected for the present study. Descriptive statistical analyses were done for the Likert type questions (ie, frequency analysis, measures of central tendency, and dispersion), and final data were scrutinized under Chi-square and Pearson correlation coefficients formula. To ensure content and face validity, the 42- item 
questionnaire, with 6 subscales (behavioral intention, perceived usefulness, perceived ease of use, content quality system accessibility, subjective norm, and e-learning self- efficacy were designed and distributed among teachers. Then, to ensure reliability, the questionnaire was distributed among some university teachers, and the Cronbach's alpha was confirmed for each subscale (0.72, 0.90, $0.70,0.75,0.85,0.87$ ). In the questionnaire, there were several questions about the time and chance the teachers dedicated to implicate different types of technology such as personal computer, tablet, and laptop and the way they communicated with students to manage the learning process (on and off job activities) each day. The target sample was selected from Mashhad scientific panel, among whom 150 individuals were selected based on random stratified sampling method in 5 faculties.

Confirmatory factor analysis was used to ensure construct reliability. Table 1 demonstrates a summary of factor analysis, and the overall model fit measures of test construct reliability was considerable.

Table 1. Confirmatory Factor Analysis of Construct Reliability

\begin{tabular}{lcc}
\hline Goodness of Fit Model Index & Minimum P Value & Result \\
\hline$\chi^{2}$ & & 445.89 \\
$\chi^{2}$ sig & $<0.05$ & 0.001 \\
\hline$\chi^{2}$ on DF & $>3$ & 2.06 \\
\hline RMSEA & $>0.08$ & 0.07 \\
\hline GFI & $<0.09$ & 0.93 \\
\hline NFI & $<0.09$ & 0.95 \\
\hline NNFI & $<0.09$ & 0.93 \\
\hline
\end{tabular}

As demonstrated in Table 1 , the $\chi^{2}$ test result has proper sig and absolute measures were significant and considered acceptable. In addition to absolute values, the root mean squared error of approximation (RMSEA), the goodness-offit index (GFI), and NFI, as comparative fit measures, were examined. NFI ranges from 0 to 1 , with values exceeding.9, indicating a good fit.

\section{Results}

Demographic information of the sample is illustrated at the Table 2 separated by age, gender, academic degree in different faculties.

Table 3 demonstrates statistical description of each variable

The variable of e-learning self-efficacy has the highest mean score and behavioral intention has the least.
Table 2. Demographic Information of the Sample

\begin{tabular}{|c|c|c|c|c|c|c|c|}
\hline Faculty & $\mathbf{N}$ & $\begin{array}{l}\text { Age and } \\
\text { Work } \\
\text { Dura- } \\
\text { tion (by } \\
\text { Year) }\end{array}$ & $\mathbf{N}$ & $\begin{array}{l}\text { Academic } \\
\text { Degree } \\
\text { of } \\
\text { Teachers }\end{array}$ & $\mathbf{N}$ & Gender & $\mathbf{N}$ \\
\hline $\begin{array}{l}\text { Persian } \\
\text { and } \\
\text { foreign } \\
\text { lan- } \\
\text { guages }\end{array}$ & 39 & $25-35$ & 13 & Lecturer & 17 & Male & 47 \\
\hline $\begin{array}{l}\text { Geography } \\
\text { and } \\
\text { Engi- } \\
\text { neering }\end{array}$ & 22 & $35-45$ & 47 & $\begin{array}{c}\text { Assistant } \\
\text { prof. }\end{array}$ & 115 & Female & 107 \\
\hline $\begin{array}{l}\text { Education } \\
\text { and Psy- } \\
\text { chology }\end{array}$ & 30 & $45-55$ & 54 & $\begin{array}{c}\text { Associate } \\
\text { prof }\end{array}$ & 18 & \multicolumn{2}{|c|}{ Total: 150} \\
\hline $\begin{array}{l}\text { Biology } \\
\text { and } \\
\text { Chem- } \\
\text { istry }\end{array}$ & 28 & Up to55 & 36 & & & & \\
\hline $\begin{array}{l}\text { Sport } \\
\text { sciences }\end{array}$ & 31 & & & & & & \\
\hline
\end{tabular}

Table 3. Analytic Description of Variables Measurement

\begin{tabular}{lccc}
\hline Variables & Mean \pm std & Min & Max \\
\hline Behavioral intention & $1.92 \pm 0.69$ & 1 & 3 \\
\hline Perceived usefulness & $3.64 \pm 0.52$ & 1 & 3.75 \\
\hline Perceived ease of use & $2.79 \pm 0.58$ & 1 & 3.83 \\
\hline Data quality & $3.47 \pm 0.37$ & 1 & 3.88 \\
\hline System accessibility & $2.45 \pm 0.41$ & 1 & 3.50 \\
\hline Subjective norm & $3.65 \pm 0.50$ & 1 & 3.60 \\
\hline E-learning self-efficacy & $3.97 \pm 0.60$ & 1 & 3.17 \\
\hline
\end{tabular}

Table 4 displays the correlation among variables. The correlation of all items with inclination of technology acceptance was proved by meaningful sig $(\mathrm{P}<0.001)$. The highest score for correlation was given to variables' subjective norm and perceived ease of use, meanwhile the lowest score for correlation was between system accessibility and e-learning self-efficacy.

The answers to the research questions are provided in Table 5.

As demonstrated in Table 5, there was a correlation between variables' perceived usefulness and behavioral intention (0.323), which is significant at a meaningful level ( $\mathrm{P}$ $<0.001$ ). Also, there was a correlation between perceived ease of use and behavioral intention (0.656), which was significant at a meaningful level $(\mathrm{P}<0.001)$. In Table 5 , content quality and behavioral intention showed a significant difference at a meaningful level in the correlation score es- 
Table 4. Summary of Variables as Correlation of Matrix

\begin{tabular}{|c|c|c|c|c|c|c|c|}
\hline & $\begin{array}{c}\text { Perceived } \\
\text { Usefulness }\end{array}$ & $\begin{array}{c}\text { Perceived Ease } \\
\text { of Use }\end{array}$ & Data Quality & $\begin{array}{c}\text { System } \\
\text { Accessibility }\end{array}$ & $\begin{array}{l}\text { Subjective } \\
\text { Norm }\end{array}$ & $\begin{array}{l}\text { E-Learning } \\
\text { Self-Efficacy }\end{array}$ & $\begin{array}{c}\text { Behavioral } \\
\text { Intention }\end{array}$ \\
\hline $\begin{array}{l}\text { Perceived } \\
\text { usefulness }\end{array}$ & 1 & & & & & & \\
\hline $\begin{array}{l}\text { Perceived ease } \\
\text { of Use }\end{array}$ & 0.683 & 1 & & & & & \\
\hline Data quality & 0.487 & 0.675 & 1 & & & & \\
\hline $\begin{array}{l}\text { System } \\
\text { accessibility }\end{array}$ & 0.537 & 0.604 & 0.476 & 1 & & & \\
\hline $\begin{array}{l}\text { Subjective } \\
\text { norm }\end{array}$ & 0.70 & 0.817 & 0.606 & 0.586 & 1 & & \\
\hline $\begin{array}{l}\text { E-learning } \\
\text { self-efficacy }\end{array}$ & 0.420 & 0.668 & 0.436 & 0.295 & 0.613 & 1 & \\
\hline $\begin{array}{l}\text { Behavioral } \\
\text { intention }\end{array}$ & 0.323 & 0.656 & 0.494 & 0.258 & 0.624 & 0.826 & 1 \\
\hline
\end{tabular}

Table 5. Summary of Correlation of the Variables

\begin{tabular}{|c|c|c|c|c|}
\hline Variables & $\mathbf{N}$ & $\begin{array}{c}\text { Correlation } \\
\text { Coefficient }\end{array}$ & DF & Sig \\
\hline $\begin{array}{l}\text { Behavioral } \\
\text { intention }{ }^{\mathrm{a}} \text { Perceived } \\
\text { usefulness }\end{array}$ & 150 & 0.323 & 149 & $<0.001$ \\
\hline $\begin{array}{l}\text { Behavioral } \\
\text { intention }{ }^{\mathrm{a}} \text { Perceived } \\
\text { Ease of Use }\end{array}$ & 150 & 0.656 & 150 & $<0.001$ \\
\hline $\begin{array}{l}\text { Behavioral } \\
\text { intention }{ }^{\mathrm{a}} \text { Data } \\
\text { quality }\end{array}$ & 150 & 0.494 & 150 & $<0.001$ \\
\hline $\begin{array}{l}\text { Behavioral } \\
\text { intention }{ }^{\text {a }} \text { System } \\
\text { accessibility }\end{array}$ & 150 & 0.258 & 150 & $<0.001$ \\
\hline $\begin{array}{l}\text { Behavioral } \\
\text { intention }{ }^{\mathrm{a}} \text { Subjective } \\
\text { norm }\end{array}$ & 150 & 0.624 & 150 & $<0.001$ \\
\hline $\begin{array}{l}\text { Behavioral } \\
\text { intention }^{\mathrm{a}} \text { E-learning } \\
\text { self-efficacy }\end{array}$ & 150 & 0.826 & 150 & $<0.001$ \\
\hline
\end{tabular}

${ }^{\mathrm{a}}$ Correlation Coefficient at $\mathrm{P}<0.01$.

timated by 0.494 between variables $(\mathrm{P}<0.001)$.The correlation between system accessibility and behavioral intention (estimated by 0.258 ) was significant at a meaningful level $(\mathrm{P}<0.001)$.The correlation between subjective norm and behavioral intention (estimated by 0.624 ) is significant at a meaningful level $(\mathrm{P}<0.001)$. The correlation between elearning self-efficacy and behavioral intention (estimated by 0.826$)$ was significant at meaningful level $(\mathrm{P}<0.001)$.

\section{Discussion and Conclusions}

Based on the technology acceptance model (TAM), the objective of this study was to investigate what internal factors influence technology acceptance as e-learning system in Iranian universities from the teachers' point of views. As much as people around the world use technology in their daily activities, it is desired to demonstrate and predict the impacts of internal factors such as ease and usefulness on their behavioral intention. Based on the research questions, we proposed that there is a relationship between content quality and system accessibility with behavioral intention to technology acceptance. As discussed in the research findings, the correlation of factors is accepted and it demonstrated a positive relationship between the mentioned factors. This finding is in accordance with researches $(6,10)$ which emphasized on the impacts of technology ease and usefulness, social factors, subjective norm, system and facilities quality on behavioral intention. Moreover, the positive relationship has been confirmed between students' approach to use technology and the mentioned factors.

Findings of Paola Torres Maldonado et al. study(12) and common researches $(9,10)$ explained the role of e-learning motivation and social factors in the use and adoption of elearning systems and conversely the effect of technology on students' e-learning motivation. The research finding in this regard was also confirmed that the impacts of computer self-efficacy and perceived ease of use were able to explain users' intention to e-learning system, with a positive approach on technology in universities.

Preparation of interactive environment to activate the teaching and learning process in universities is undergrounded in conceptualization of system accessibility for teachers and students. The research findings indicated the impact of system accessibility conceptualization on teachers and students in modifying teaching-learning qualification and a proper approach to use technology in university. 
Moreover, content quality was affirmed as an important variable in this paper. The desirable findings of the researches have been prepared by researchers $(7,14)$ and according to our finding in the present study, e-learning course flexibility and course quality affect perceived usefulness and behavioral intention. Content quality should be up to date, which as a critical factor affects learners' perceived satisfaction.

Computer and web-based environment has a proper potential for interactive contractions and it leads to socioeconomic changes in countries. In Iranian higher education system, especially with governmental administration, which is going to improve their qualification gradually, it is suggested to prepare desirable experimental changes for technology users at the start of their interactions. It is also recommended that universities provide technologic facilities with ease of use to help students and teachers implicate their achievements in using technology to do important activities in minimizing date and time.

\section{Footnote}

Authors' Contribution: Study concept, design and critical revision of the manuscript for important intellectual content were developed by the authors who participated through the overall process.

\section{References}

1. Khorasani A, Abdolmaleki J, Zahedi H. Analysis of the factors has effects on E-based learning acceptance among the students of Medical Science University on Tehran based Technology Acceptance Model (TAM). Iran J Med Sci. 2000;11(6):43-56.
2. Davis FD, Bagozzi RP, Warshaw PR. User Acceptance of Computer Technology: A Comparison of Two Theoretical Models. Manag Sci. 1989;35(8):982-1003. doi: 10.1287/mnsc.35.8.982.

3. Davis FD. Perceived Usefulness, Perceived Ease of Use, and User Acceptance of Information Technology. MIS Q. 1989;13(3):319. doi: 10.2307/249008

4. Mathieson K. Predicting User Intentions: Comparing the Technology Acceptance Model with the Theory of Planned Behavior. Inf Systems Res. 1991;2(3):173-91. doi: 10.1287/isre.2.3.173.

5. Dorani K, Rashidi Z. Factors influencing the adoption of IT by teachers smart schools in Tehran with emphasis on Information Technology Acceptance. J Inf Sci Technol. 2007;1:23-46.

6. van Raaij EM, Schepers JJL. The acceptance and use of a virtual learning environment in China. Comput Educ. 2008;50(3):838-52. doi: 10.1016/j.compedu.2006.09.001.

7. Sun PC, Tsai RJ, Finger G, Chen YY, Yeh D. What drives a successful e-Learning? An empirical investigation of the critical factors influencing learner satisfaction. Comput Educ. 2008;50(4):1183-202. doi: 10.1016/j.compedu.2006.11.007.

8. Nichols AJ. An empirical assessment of attitude toward computers, motivation, perceived satisfaction from the e-learning system, and previous academic performance and their contribution to persistence of college student athletes enrolled in e-learning courses. Nova Southeastern University; 2008.

9. Yuen AHK, Ma WWK. Exploring teacher acceptance of e-learning technology. Asia Pac J Teach Educ. 2008;36(3):229-43. doi: $10.1080 / 13598660802232779$.

10. Kim J. User acceptance of web-based subscription databases: Extending the technology acceptance model. Florida State University; 2005.

11. Kunda D, Brooks L. Assessing important factors that support component-based development in developing countries. Inf Technol Dev. 2010;9(3-4):123-39. doi: 10.1080/02681102.2000.9525327.

12. Paola Torres Maldonado U, Feroz Khan G, Moon J, Jeung Rho J. E-learning motivation and educational portal acceptance in developing countries. Online Inf Rev. 2011;35(1):66-85. doi: $10.1108 / 14684521111113597$.

13. Hossain L, de Silva A. Exploring user acceptance of technology using social networks. J High Technol Manag Res. 2009;20(1):1-18. doi: 10.1016/j.hitech.2009.02.005.

14. Rocha P, Siddiqui A, Stadler M. Improving energy efficiency via smart building energy management systems: A comparison with policy measures. Energy Buildings. 2015;88:203-13. doi: 10.1016/j.enbuild.2014.11.077. 